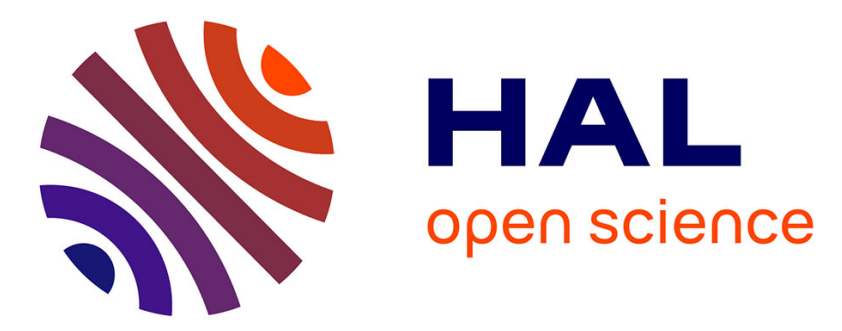

\title{
Gravettian Projectile Points: Considerations About the Evolution of Osseous Hunting Weapons in France
}

\author{
Nejma Goutas
}

\section{To cite this version:}

Nejma Goutas. Gravettian Projectile Points: Considerations About the Evolution of Osseous Hunting Weapons in France. Michelle C. Langley. Osseous projectile weaponry: Towards an understanding of Pleistocene cultural variability, Springer, pp.89-107, 2016, Vertebrate Paleobiology and Paleoanthropology, 978-94-024-0897-3. 10.1007/978-94-024-0899-7_7 . hal-01961350

\section{HAL Id: hal-01961350 https://hal.science/hal-01961350}

Submitted on 19 Dec 2018

HAL is a multi-disciplinary open access archive for the deposit and dissemination of scientific research documents, whether they are published or not. The documents may come from teaching and research institutions in France or abroad, or from public or private research centers.
L'archive ouverte pluridisciplinaire HAL, est destinée au dépôt et à la diffusion de documents scientifiques de niveau recherche, publiés ou non, émanant des établissements d'enseignement et de recherche français ou étrangers, des laboratoires publics ou privés. 


\title{
Chapter 7 \\ Gravettian Projectile Points: Considerations About the Evolution of Osseous Hunting Weapons in France
}

\author{
Nejma Goutas
}

\begin{abstract}
The transition from the Aurignacian to the Gravettian witnessed important environmental, economic and social changes. These changes are especially evident in hunting weapons. Some Aurignacian points (split-based points) disappear from the archaeological record, others (simple-based points) remain, and new types (bevelled based points) appear, some of which will persist long after the Gravettian. Others become characteristic of the Gravettian, with some specific to certain phases ('Isturitz points', simple-based points with mesial incisions). In contrast with the Aurignacian, Gravettian projectile points become more and more refined and standardized. These changes are closely related to the introduction of a new method of blank extraction: the 'debitage by extraction with the groove and splinter technique' (DE with GST). Owing to the diversity of sedimentary, environmental, and cultural contexts in which Gravettian techno-complexes are found, this chapter will focus on osseous points discovered in France. The economic, environmental, and sociological factors involved in the transformation of this equipment during the Gravettian is outlined and discussed.
\end{abstract}

Keywords Gravettian • France - Osseous projectile point • Hafting system $\bullet$ Economical changes $\bullet$ Groove and splinter technique

N. Goutas $(\square)$

CNRS, ArScAn, UMR-7041, Équipe Ethnologie Préhistorique, 21, allée de l'Université, F-92023 Nanterre, Cedex, France

MAE - Maison René Ginouvès - Archéologie and Ethnologie, 21, allée de l’Université, F-92023 Nanterre, Cedex, France e-mail: nejma.goutas@mae.cnrs.fr

\section{Introduction}

In this chapter, I will provide a synthesis on Gravettian osseous weaponry in France. This synthesis will revolve around several issues: what raw materials were used?, how were these weapons manufactured?, what morphotypes are known in the French Gravettian?, are all types historically reported really hunting weapons?, what do we know about the evolution of this equipment within the Gravettian?, are any points chrono-cultural markers of the Gravettian?, or even a specific phase of the French Gravettian?; and how do we interpret the changes which characterize the osseous Gravettian weapons? This work is based mainly on assemblages from seven French Gravettian sites (12 collections in total), relating to all phases of the Gravettian (Goutas 2004, 2009, 2008, 2013a), and complemented with published data. With the exception of Arcy-sur-Cure, located in Bourgogne (Renne and Trilobite caves), the studied sites are located in southwest France where most of the Gravettian osseous industries are found (Fig. 7.1).

\section{Gravettian Osseous Projectile Points}

The Gravettian is the second techno-complex of the Upper Paleolithic (30,000-20,000 uncal BP), succeeding the Aurignacian. It developed throughout Europe between the end of the Interpleniglacial (OIS 3) and the beginning of the Last Glacial Maximum (OIS 2), occurring in the context of general climate cooling in Europe, interspersed with warmer or more humid phases (Dansgaard-Oeschger interstadials 3 and 4) (Sanchez-Goñi and Harrison 2010; Blockeley et al. 2012).

In France, the oldest Gravettian industries date to around 29,000-28,000 uncal BP. According to the recent synthesis proposed by Pesesse (2013:79-80), we can distinguish seven 


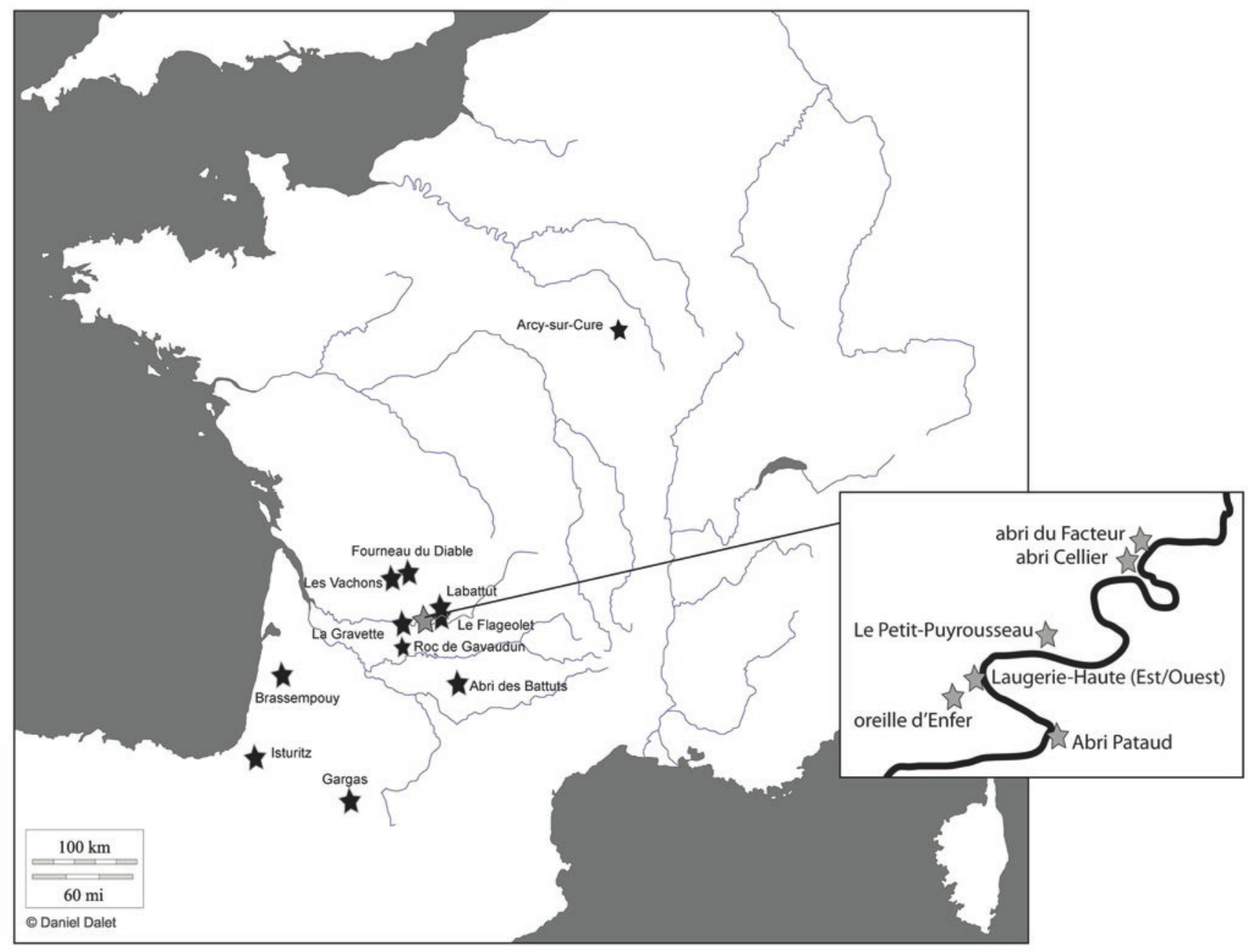

Fig. 7.1 Map of the main French Gravettian sites having delivered osseous industry (GEOATLAS, copyright 1999, Graphi-Ogre, modified map)

facies which can be grouped into four major chronological phases:

(1) An early phase (29-26 ka uncal BP): Including Bayacian, the Early Gravettian sensu stricto, and Gravettian with Font-Robert points or Fontirobertian.

(2) A middle phase (26-24 ka uncal BP): Gravettian with Noailles burins or Noaillian, and the Gravettian with Raysse burins or Rayssian.

(3) A recent phase: Also called 'Recent Gravettian'; and

(4) A final phase: Related to the Protomagdalenian industries or final Gravettian.

In France, Upper Paleolithic osseous weaponry is made mainly of cervid (mainly reindeer) antler (Fig. 7.2a). Unlike the Aurignacians (Liolios 1999; Tartar 2009; Tejero 2013), however, Gravettians did not use reindeer antler exclusively for hunting points, but also for other tools (e.g., bâtons percés, wedges etc.). Despite this fact, points made on bone are rare in France and are usually found restricted to a single or few items found in a limited number of sites (i.e., Isturitz, La Gravette, Laugerie-Haute, La Ferrassie). In the Gravettian economy, bone was instead mainly used for manufacturing domestic tools (Goutas 2004). The use of ivory is also rare in the Gravettian assemblages of France, as its use for projectile points, though it is more common than bone. In many sites, ivory points are found restricted to a few items, such as in the Noaillian levels of Isturitz cave, in the final Gravettian of Laugerie-Haute and the Labattut shelter (Alaux 19671968; Goutas 2004). Some sites, however, are distinguished by an unusual concentration of ivory points: either because of the quantity of points recovered, the characteristic of the points themselves, or even the particular context of their discovery. 


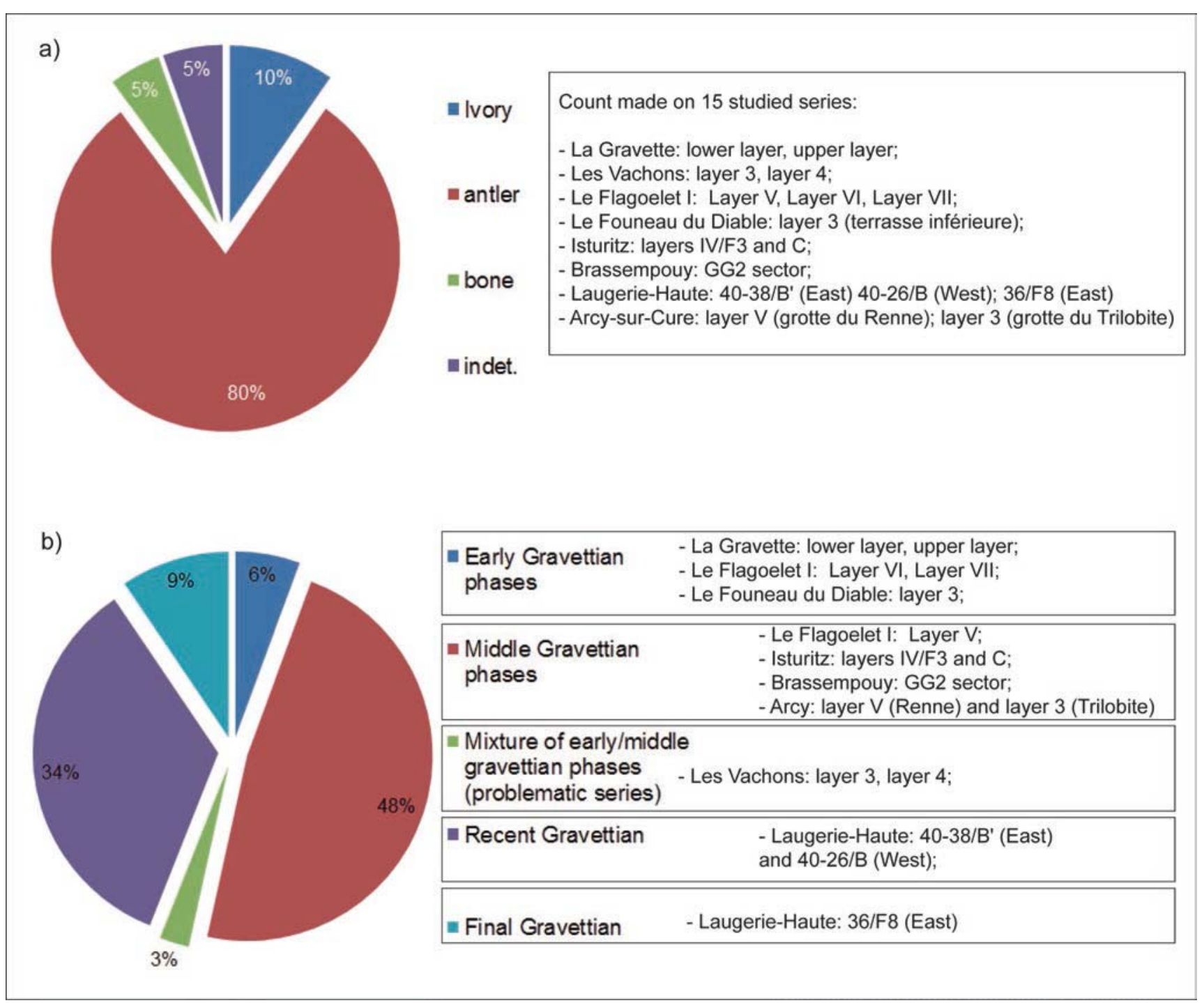

Fig. 7.2 Composition of Gravettian osseous point dataset (a) Raw materials used in French Gravettian sites; (b) Percentage of osseous points in the various main phases of the Gravettian

This first situation is the case for the recent Gravettian of Laugerie-Haute which has delivered twenty ivory points (Goutas 2004) associated with numerous lithic burins. Many of these points exhibit characteristic use wear of ivory working, suggesting shaping and perhaps in situ production of the implements (Christensen 1999). Arcy-surCure (Rayssian facies) delivered seven massive section ivory points among which six are 'Isturitz points' although they also show specific technical and morphological features (see below) (Goutas 2013a). The last scenario is found at Brassempouy where a narrow space (GG2 sector) away from the main activity area and located about fifteen meters from the first Venus figurine, produced eight decorated ivory points associated with 102 lithic points. All of these projectiles points were not produced at this site, but were intentionally brought to and abandoned there, in some cases, after being used. The significance of this last assemblage is not yet clear, though its isolation, the investment in its manufacture, as well as the specificity of the used material, suggests an intentional and perhaps symbolic "exclusion" (Goutas and Simonet 2009).

\section{Composition of the Osseous Weaponry Assemblages}

One of the most distinctive characteristics of Gravettian points is the mix of technical and morphological criteria, as illustrated in Table 7.1. Some points are typologically at the junction of two different types, however, several distinct types exist. 


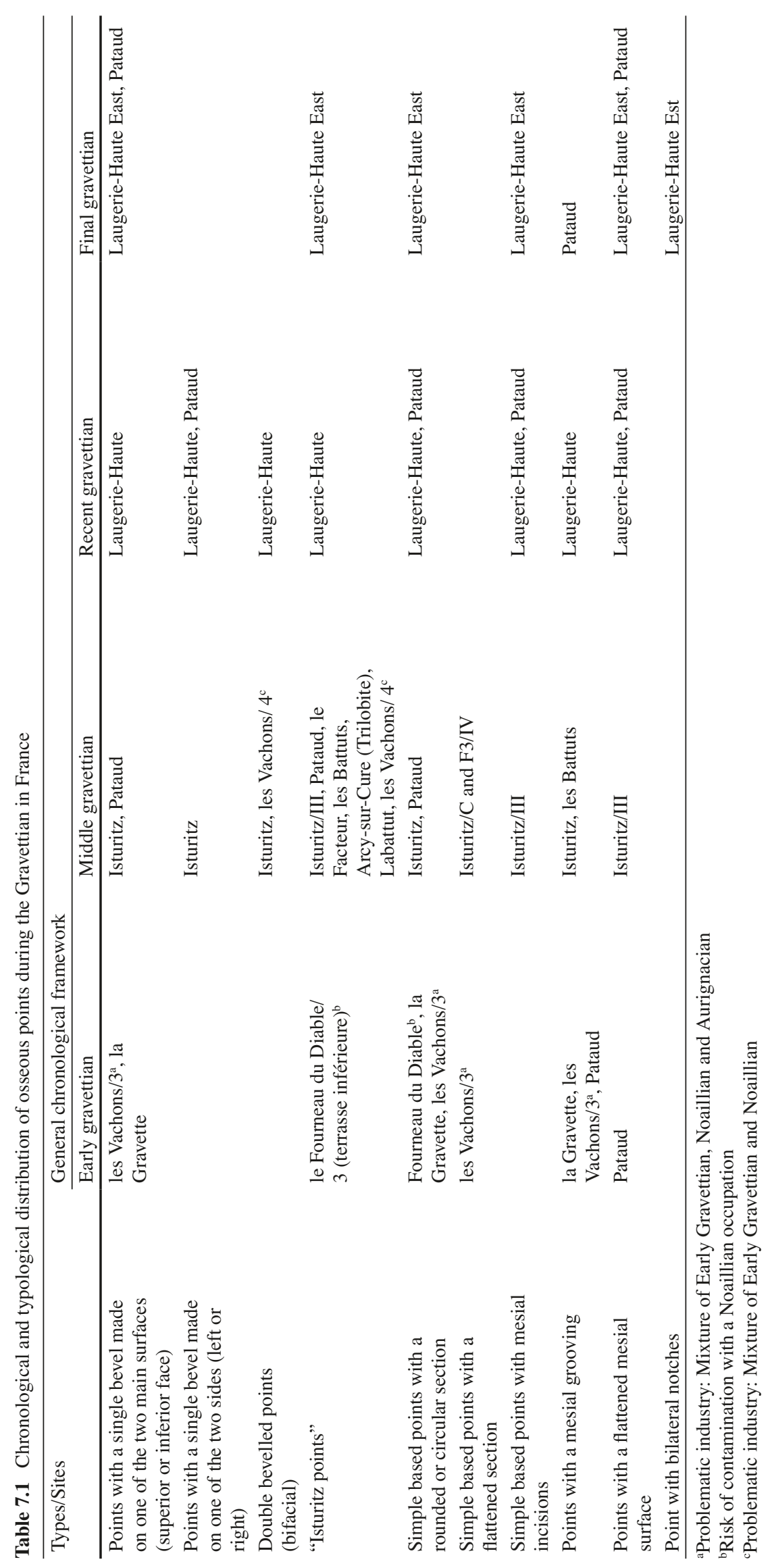




\section{Simple Based Points (Fig. 7.3a)}

Also known as 'simple double-points' or 'biconoical points', the typo-technological data are not yet sufficiently advanced to highlight major differences in terms of shape and manufacture of this point type during the Gravettian, though it is noted that those which have been found in the Noaillian of Isturitz are wider and have a more flattened section than those known in the recent and final Gravettian of LaugerieHaute (which have a rounded section).

The simple based points of Isturitz fall into two groups, depending on their size and on the morphology of their distal end:

1. Very narrow points whose distal end is relatively sharp and is formed by the convergence of the straight edges. On some points, the shaft has parallel edges which converge abruptly at the proximal end. The transition zone between these two sections is connected by a break in the profile, sometimes accentuated by a slight lateral offset of the proximal end. These points are on average 5-6 mm wide and 2-3 mm in thickness. Sections within this group are exclusively biconvex or flattened oval.

2. More massive section points. The distal end is usually smooth, with a 'spindle-shaped morphology'. There is not, at this section, a break between the shaft and the proximal end: the edges gradually converge towards the latter which gives an almost lozenge shape morphology.

A number of points form a continuum between these two morphological groups. Many simple based points exhibit use fractures caused by flexion (step, bevel, or splinter).

\section{Single Bevelled Points (Fig. 7.3b)}

According to Knecht (2000), single bevelled points are characteristic of Western Europe during the Gravettian. In France, these points are divided into two main sub-types (Fig. 7.3d-g):

(1) Points with a single bevel made on one of the two main surfaces (superior or inferior) of the point (pointe à biseau simple facial); and

(2) Points with a single bevel made on one of the two sides (left or right) of the point (pointe à biseau simple latéral).

According to Knecht, these points are primarily made on bone, however, my own observations have found that they are mainly of cervid antler (Goutas 2004). This difference in point of view is probably owing to the fact that Knecht took into account the large bone points found in the final Gravettian of Laugerie-Haute. For me, these points are intrusive and would come from overlying levels related to the 'Aurignacian V' (Proto-Solutrean). On the other hand, rare bone points which are thinner and smaller than these large examples, and which underwent a very different shaping process, seem to truly belong to the Gravettian. Knecht's assertion probably also relies on points discovered in the Upper Gravettian layer of Isturitz (layer III), which was excluded from this analysis. This level provides evidence of numerous contamination events from the Solutrean and Magdalenian layers, and the bone single bevelled points (with a circular section) which were found at this location are actually Solutrean (Fig. 7.4d-f). Their characteristics (raw material, morphology, size, techniques of shaping the bevel) are radically different from those identified in the underlying Gravettian levels. Additionally, there are identical points in the Solutrean of Isturitz (layer IIIa) and in the Aurignacian V of Laugerie-Haute (Goutas 2004:112-114).

Single bevelled points (some with striations on the bevel) are represented at several sites, but always limited in number. For example, Féaux reports a point with a "thin and exceptionally long bevel" from the upper layer of La Gravette (Sonneville-Bordes 1960:181). Layer 3 of Les Vachons, whose lithic industry attests to mixing between the Aurignacian and Early Gravettian (Pesesse 2008), perhaps with a Noaillian occupation, has also delivered a similar item (Goutas 2004). Items possibly indicative of the Early Gravettian phases, are thus, very rare.

During the Middle Gravettian, single bevelled points are known at Isturitz (F3/IV), where three examples exclusively made from reindeer antler and including a second intended point and one with an incised bevel are found. A fourth piece may also belong to this category. The Noaillian of Pataud (layer 4) also delivered three points (Bricker and David 1984), and Labattut shelter two (Alaux 1967-1968). Finally, for the same facies, Le Facteur shelter delivered a bone point with a slightly flattened convex bevel (Peyrony 1934). In contrast, in the Rayssian layer 5 of Le Flageolet I (Goutas 2004), these points are not known, but in the same context in Arcy-sur-Cure (Grotte du Trilobite/ layer 3), one example was discovered (Goutas 2013a).

For the recent Gravettian, they are known at LaugerieHaute East and West $(n=13)$, where with the exception of one point made on ivory, only antler was used. Four of them have an incised bevel (Goutas 2004). One possible example could be present in layer 3 of Pataud (Bricker 1995), and in the final Gravettian, they are represented at Laugerie-Haute by seven examples, among which four are in antler and three on an indeterminate material. Two also have incised bevels (Goutas 2004). Points are also present in layer 2 of Pataud (Bricker 1995). Finally, in a less obvious contexts, de 


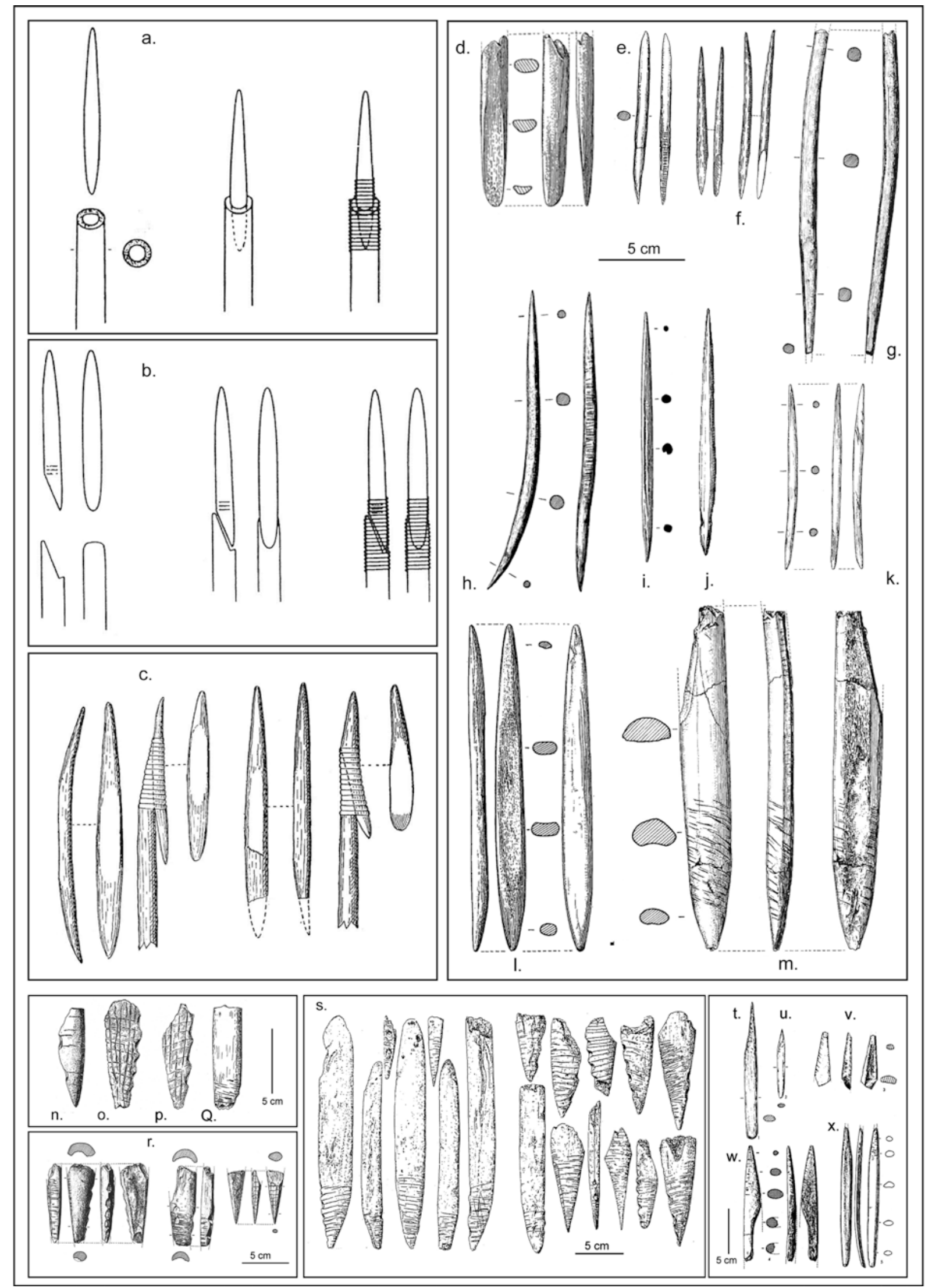

Fig. 7.3 Points and hafting systems identified in French Gravettian sites: (a) Socket-like hafting system with a single based point (after Knecht 1991b, fig. 4); (b) "Hafting by contact" system with a single bevelled point (after Knecht 1991b, fig. 4); (c) "Hafting by contact" system with a bipoint with a flattened mesial surface (Peyrony and
Peyrony 1938, fig. 12: 23); (d) single beveled point from Pataud, final Gravettian (after Bricker 1995, fig. 20-c: 84); (e) single and incised beveled point from Laugerie-Haute (after Knecht 1991b, Fig. 1:121); (f) single beveled points from Laugerie-Haute, recent Gravettian (Peyrony and Peyrony 1938, fig. 6-6, 7: 15); (g) single lateral beveled 


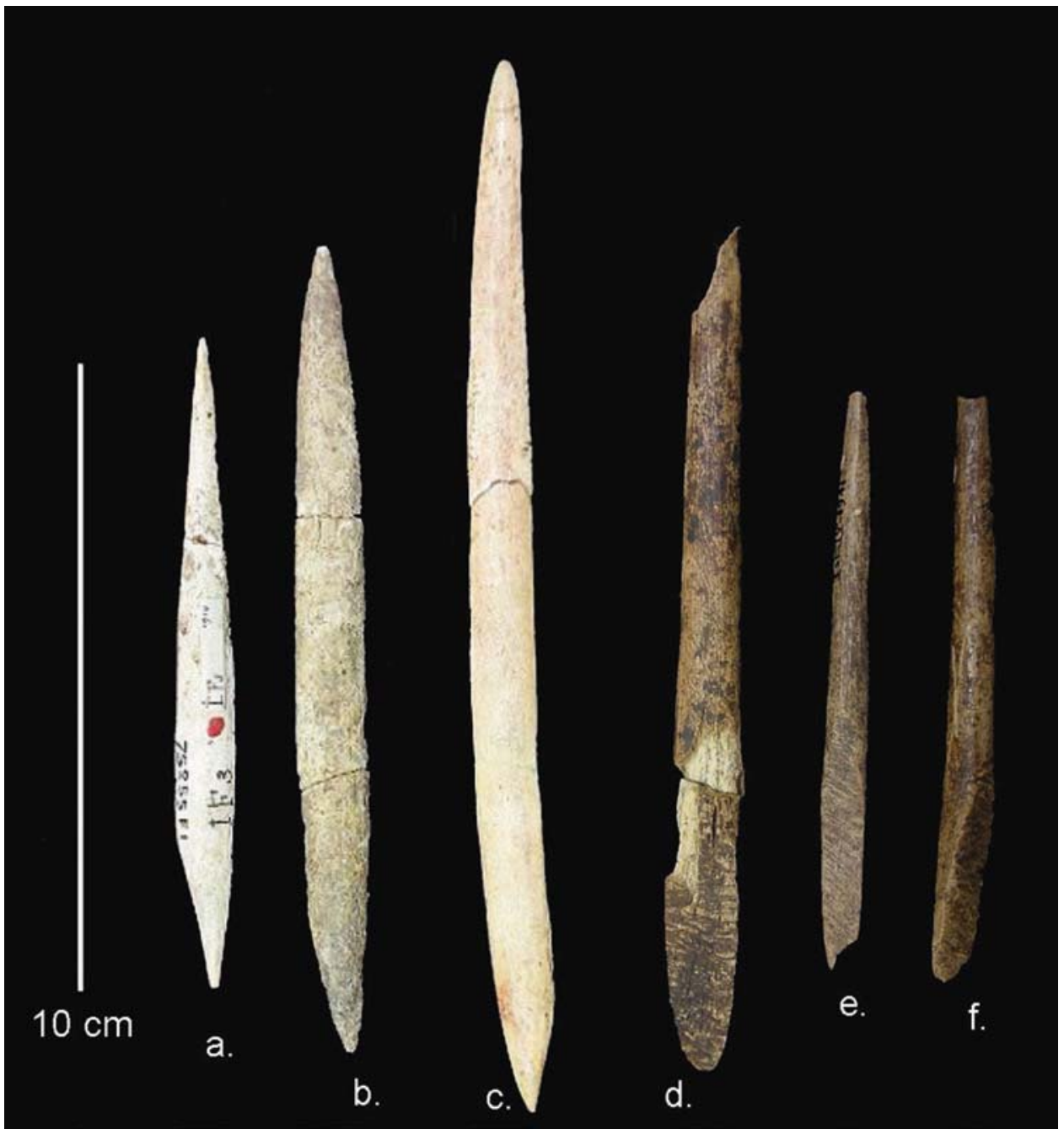

Fig. 7.4 Points from Isturitz Cave (Pyrénées-Atlantiques): (a-c) simple based points made on antler with a slight lateral offset of the proximal end (lower layers); (d-f) single and incised bevelled bone points

Sonneville-Bordes (1960) and Bricker (1995) reported an item with transverse striations in the 'Upper Périgordian' of Abri Pagès du Ruth (level D), while two probable single bevelled points were found in Laussel in a similar Gravettian level, according to Bouyssonie, the layers $\mathrm{J}$ and $\mathrm{K}$ of $\mathrm{La}$ Ferrassie (Sonneville-Bordes 1960).

In the assemblages I studied, there are both morphometric similarities and differences according to the chrono-cultural contexts in which these points were found. Whatever the (upper layer III). Musée d'Archéologie Nationale, Saint-Germain-enLaye. photographs@ Nejma Goutas

context, however, single bevelled points have a medium or small size. For example:

- In Gravettian layer 3 at Les Vachons (predominantly Early Gravettian), the only single bevelled point found has a width of $16 \mathrm{~mm}$ and a thickness of $7 \mathrm{~mm}$.

- In the Noaillian of Isturitz width varies between 7 and $13 \mathrm{~mm}$, with a thickness ranging from 6 to $9 \mathrm{~mm}$. In the Rayssien of Trilobite cave in Arcy-sur-Cure (layer 3), the
Fig. 7.3 (continued) point from Pataud, recent Gravettian (after Bricker and David 1984, Fig. 31-5:98); (h) bipoints with mesial incisions from Pataud, recent Gravettian (after Bricker and David 1984, Fig. 31-1:98); (i) point with mesial grooving from Pataud (after Bricker 1995, fig. 20-1: 84); (j) point with bilateral notches from Laugerie-Haute, final Gravettian (after Bordes 1958, fig. 22-15); (k) single based point from Pataud, recent Gravettian (after Bricker and David 1984, Fig. 31-6:98); (l) point with a flattened mesial surface from Pataud, final Gravettian (after Bricker 1995, fig. 20-b: 84); (m) "Isturitz point" from Pataud, Noaillian (after David 1985, fig. 45); (n to q) various fragments of "Isturitz points" from Gargas (n), Labattut $(\mathbf{o}, \mathbf{p})$, Téoulé (q) (after Saint-Périer and Saint-Périer 1952, fig. 68: 128); (r) "Isturitz points" from Pataud, Noaillian (David 1985, fig. 47); (s) "Isturitz points from Isturitz cave, Noaillian (Saint-Périer and Saint-Périer 1952, fig. 66, 67); $(\mathbf{t}-\mathbf{x})$ "Isturitz points from Le Facteur (t, u), Les Battuts $(\mathbf{v})$, Roc de Combe (w), Roc de Gavaudun (x) (after Sonneville-Bordes 1972, fig. 2: 3) 
only single based point discovered has a width of $7 \mathrm{~mm}$ and a thickness of $5 \mathrm{~mm}$.

- In the recent Gravettian of Laugerie-Haute, points vary between 5 and $10 \mathrm{~mm}$ in width and between 4.5 and $9 \mathrm{~mm}$ in thickness;

- In the final Gravettian of this same site, width varies between 3 and $15 \mathrm{~mm}$ with thicknesses between 3 and $10 \mathrm{~mm}$.

Only the recent Gravettian of Laugerie-Haute and layer 3 of Les Vachons have each delivered a complete artefact, in both cases with a length of $116 \mathrm{~mm}$. An almost complete item from Laugerie-Haute, however, has an exceptional length of $385 \mathrm{~mm}$, a width of $12 \mathrm{~mm}$ and a thickness of $10 \mathrm{~mm}$.

For sections, both in the recent and final Gravettian, points with a single bevel are oval to elliptical (LaugerieHaute, Les Vachons), whereas at Isturitz, in the Noaillian levels, planoconvex, biconvex and subtriangular sections are also seen.

On the bevel, in the middle Gravettian of Isturitz and the early Gravettian of Les Vachons, they are usually fairly short and have a flat surface. However, in the recent and final Gravettian of Laugerie-Haute, the bevel is usually very long, often curved, and ends with a sharpened extremity. On some, the bevel constitutes a third or even one half of the point's total length.

According to the data from Isturitz and Laugerie-Haute, it would thus appear that significant differences in the shape of single bevelled points may foreshadow an evolution of this type during the Gravettian. However, these data remain to be verified. Moreover, the situation is not so simple, as according to the illustrations published by David (1985), the Noaillian single bevelled points of Pataud differ from those of Isturitz. These latter artefacts present more similarities with those of the recent and final Gravettian of Laugerie-Haute, while the final Gravettian of Pataud has one point reminiscent of those of Isturitz (Fig. 3d). The single bevelled points from the Noaillian of Pataud are also very close to those found in Layer 3 of Les Vachons, and the Les Vachons point may then be intrusive. It could, in fact, come from layer 4 (upper), which is mainly referable to the Noaillian phase (Pesesse 2008; Simonet 2011).

\section{Double Bevelled Points}

Double bevelled points are rarer than single-bevelled points. An artefact was found in the early Gravettian of La Gravette (upper Layer, with Gravette points), and another comes from Les Vachons, layer 4, which is mainly related to a Noaillian phase (Pesesse 2008). At this latter site, the bifacial bevel is carved and the shaft carries a longitudinal groove on its upper surface. Another example is found in the Noaillian of Isturitz cave (layer F3/IV), while the recent Gravettian of
Laugerie-Haute delivered three points of this type. Here, one point has a bifacial bevel with incisions, while another exhibits a bilateral bevel. At this site, their section is oval, elliptical or subquadrangular. The only near-complete point of this type measures $160 \mathrm{~mm}$ in total length (Goutas 2004). A few cases are also reported from La Roque SaintChristophe ( $\mathrm{n}=1$ : Peyrony 1939), the Grand Abri de Laussel (Bricker 1995), and within layer E of Roc de Combe-Capelle $(\mathrm{n}=2$ : Sonneville-Bordes 1960).

Points with a double bevel seem, however, missing from the final Gravettian, while a possible new type of point that we call 'point with bilateral notches' ('pointes à étranglement proximal') seem to now appear.

\section{Points with Bilateral Notches (Fig. 7.3j)}

This particular type is present in the final Gravettian of Laugerie Haute, and is a thin double-point having in its proximal (or distal) section a small constriction created by two lateral notches (Fig. 7.3j). Three such artefacts have been recovered, two made from bone and one from reindeer antler; this last being of a slightly larger size. Their width varies between 4 and $8 \mathrm{~mm}$, thickness $3-7 \mathrm{~mm}$. The only complete specimen measures $143 \mathrm{~mm}$ in total length (Goutas 2004).

A similar type is reported by Kozlowski and Kozlowski (1977) for the recent phase of the Pavlovian (dated around 25-24,000 uncal BP) at the site of Moravany-Zakovska. This point corresponding to the subcategory 3.5 of the authors typology, and is sub-cylindrical with a conical base separated by a constriction. For France, we found this type only in Laugerie-Haute. Whether this point is a type specific to this site, or more generally to the final Gravettian we are not currently able to determine.

\section{Points with Mesial Flattening: Gravettian or Solutrean Points?}

These points exhibit mesial flattening on one side of the shaft measuring several centimeters, for which Peyrony proposed the following hafting system (Fig. 7.3c, i): "The flat section was intended to be applied against the bevel of a wooden shaft and the incisions would allow a strong ligature of both sides, thus forming a kind of prototype of a harpoon arrow." (Peyrony 1932:37; author's translation).

These points are (or seem to be) pointed at both ends and are represented at Pataud in almost the entire Gravettian sequence: early phase $(n=1)$, recent phase $(n=13)$ and final phase $(n=1)$ (layers 5, 3 and 2)-with the exception of the middle Gravettian (Bricker 1995). It is also represented in the Noaillian of Isturitz cave (layer III F3/IV), and in the 
recent $(n=4)$ and final Gravettian $(n=1)$ of Laugerie-Haute (Goutas 2004).

Where these points are present in a Gravettian context, it is interesting to note that there are always Solutrean or ProtoSolutrean layers also in the stratigraphy. At these sites, points with mesial flattening are present in both the Gravettian and Solutrean levels (Isturitz, Laugerie-Haute) or only in the Solutrean level as at Le Fourneau du Diable (Peyrony 1932; Goutas 2004). While we do not know if the Proto-Solutrean (layer 1) of Pataud also presented these points, they are reported for the Solutrean and Magdalenian of Cantabria (Knecht 1997; Pokines and Krupa 1997), and in the Solutrean of Les Rideaux cave (San Juan-Foucher 2005).

All these factors pose an unresolved question: are the points intrusive in the Gravettian? Or should we consider a sustainability of this type from early Gravettian to Solutrean? To answer this question, it is necessary to directly date these points and to resume their study - in terms of their production methods, raw material and morphology-and build in-depth intra-site and intra-period comparisons in order to identify any chrono-cultural specificities or indices of contamination. The systematic research of connections between fracture surfaces of points from different layers would also be useful in order to have a critical view of their stratigraphical distribution (Pétillon 2006).

In any case, these points are mostly made from reindeer antler and the flattened surface is always arranged on the lower side of the shaft. Only two of these artefacts (discovered in layer 3 of Pataud) were made from bone or ivory. Within this layer, which delivered the majority of these particular points, artefacts are short, broad, of sub-rectangular section, and have "a flat facet sometimes incised transversely to the middle. The base is roughly cut or chopped into subconical form" (Bricker 1995:103). According to the only representation that is given for this level (Bricker 1995:101, Fig. 27g), it seems that an artefact was found with a lateral flat side which continues until the end (distal or proximal?) of the point, though in reality, we cannot assert if it also affected the shaft, as the drawn item is only a pointed fragment. If this were the case, it would not be a point with a mesial flattened surface, but instead a single lateral bevelled point, which would explain the location of the flattened surface. However, the point from Pataud/layer 5 offers a mesial and facial flattening, with the latter being associated with a groove. Finally, a point from layer 2 of Pataud is also flattened in its medium part and has smoothed, sharpened ends (Fig. 7.31; Bricker 1995).

\section{Points with Mesial Incisions}

These points are also double-ended points with an elliptical to oval section but which differ by the presence on their shaft of fine, transverse incisions that are more or less parallel.
This type is present in the recent Gravettian of LaugerieHaute $(n=6)$ and Pataud $(n=4)$. In the latter site (Bricker and David 1984), the bases are curve to the opposite side to the incisions. A point of this type is also present in the final Gravettian of Laugerie-Haute (Goutas 2004).

They are also found in the Gravettian with Noailles burins at Isturitz cave (layer III), begging one to wonder if the presence of this particular type reflects their continuation from the Noaillian phase to the recent Gravettian? Or do the points discovered in Isturitz reflect a palimpsest with a level that has a majority of Noailles age artefacts and a shorter occupation period related to a later phase of the Gravettian? Alternatively, it could be representative of a recent phase of the Noaillian where some elements of the lithic industry might be expected to be in transition (Clottes 1976; Simonet 2009).

Finally, these points with mesial incisions are reported by Peyrony and Peyrony (1938), in the Proto-Solutrean of Laugerie-Haute (Aurignacian V) where they may also be intrusive.

\section{The 'Hafting by Contact' System: A Major Gravettian Innovation?}

Biconical points, as well as the rare double bevelled points, have what is termed a 'male hafting system' (known since the Aurignacian), in which the point was inserted into a wooden shaft with a longitudinal socket (Stordeur 1987).

Bevelled based points, or those with a mesial flattened surface, inaugurated a new system: 'the hafting by contact' system (Fig. 7.3b, c; Knecht 1991a). The "projectile point and shaft are simply brought into contact against a relatively flat surface, the cohesion of the whole being secured by glue with possible ligature also used" (Pétillon 2006:18; this author's translation).

Single bevelled points, which used an oblique version of this hafting system, had the aim of reducing damage to the wooden shafts or foreshafts. This type of hafting is argued to be less destructive during violent impacts than one requiring the insertion of the point into a shaft or foreshaft (Pétillon 2006). Without invalidating or putting into question this assumption, it seems necessary to weigh the importance of single bevelled points in the Gravettian hunting systems of France. While this type of point is best represented in the later and final phases of the Gravettian at Laugerie-Haute and Pataud (Knecht 1991b:120), even here it is relatively poorly represented. In the collections of Laugerie-Haute, about twenty single bevelled points are found in the recent Gravettian and only four in the final Gravettian (Goutas 2004, 2009; cf. Knecht 1991a:470). This type of point is rare in all other phases of the Gravettian. For example, the Lower Noaillian at Pataud (layer 4) has produced only two examples (Vercoutère 2004:195). Furthermore, after a critical 
review of the stratigraphy and the osseous industry of Isturitz (upper and lower Gravettian layers), I found that some of the single bevelled points were actually intrusive and came from the overlying Solutrean and Magdalenian layers (Goutas 2004). Finally, the morphology of the most widespread Gravettian osseous points in France is not the single bevelled point, but rather the simple based point, which include various variations and which seem to suggest a diachronic evolution.

\section{Chronological Evolution of Osseous Points During the French Gravettian}

\section{Ubiquitous Points and Points with a Strong Chrono-Cultural Association}

Aurignacian split-based and the lozenge-based points disappear in the Gravettian, while simple based points persist. New types appear, among which some continue after the Gravettian (namely single bevelled points, double bevelled points, and points with a flattened mesial section or mesial grooving) (Fig. 7.3). Other types, however, are characteristic of the Gravettian and include the famous 'Isturitz point' and points with mesial incisions. Some point types are ubiquitous across the Gravettian, as is the case for simple based points, points with a facial bevel, and points with a flattened mesial surface.

On the other hand, some types are not (for the moment) attested for certain phases of the Gravettian. For example:

- Single bevelled points are known only for the middle (Isturitz) and the recent (Laugerie-Haute) Gravettian.

- Simple based points with mesial incisions are absent from the early Gravettian, with the single example from the final Gravettian (Laugerie-Haute) perhaps coming from the underlying level (recent Gravettian).

- The large simple based points with a flat section seem represented only in the Noaillian (Isturitz).

- 'Points with lateral notches' are known only in the final Gravettian (Laugerie-Haute).

- Bifacial bevel points are not attested to in the final Gravettian, whereas points with a mesial groove were not identified for the recent Gravettian

\section{Revising the Status of 'Isturitz Points' as Fossile Directeurs for the Noaillian}

For a long time, the 'Isturitz point' (stocky, with an incised end) was considered exclusive to the Noaillian (Fig. 7.3m-x), though they are now known for the Rayssien of Arcy-sur-
Cure (Goutas 2013a). Layer V of Reindeer cave at Arcysur-Cure (a layer very similar to that of layer 3 at nearby Trilobite cave), however, has also delivered two Gravette points and 18 Microgravette points (Klarics 2003). According to Klaric, this association could foreshadow mixtures between a main occupation phase relating to the middle Gravettian (with Raysse burins), and other, shorter occupations dating to a more recent phase of the Gravettian. Currently there is no consensus on the interpretation of this association (Gravette points with Raysse burins), and it is difficult to argue that it is simply the result of mixed contexts, although this possibility must be taken into account. Only the discovery of a new series from reliable chrono-stratigraphic contexts will allow an answer to this question by showing either the repetition of this association, or stratigraphical disjunction of these two lithic fossiles directeurs. Nevertheless, no evidence for a Noaillian occupation having been observed in the lithic industry, and thus, the hypothesis of contamination with Noaillian industries seems rejected. In fact, the presence of Isturitz points in Arcy-sur-Cure confirms that these particular objects are not exclusive to Noaillian facies.

The Isturitz point is also associated with recent and final Gravettian contexts at Laugerie-Haute (Goutas 2004, 2013b) and Pataud (Flori 2013), along with more questionable contexts such as the early Gravettian of Le Fourneau-du-Diable, where the closeness of a Noaillian level does not exclude the possibility of contamination (Goutas 2008). For the Noaillian, these points are attested to at numerous sites and remain a strong cultural marker of this facies. The Noaillian levels of Isturitz yielded the richest corpus in France $(n=190)$, composing more than $70 \%$ of the recorded examples. At sites other than Isturitz, and to a lesser extent, the Abri Pataud $(n=22$, San Juan-Foucher and Vercoutère 2005), Isturitz points are generally poorly represented and usually fragmented (Goutas 2008).

\section{Revising the Functional Status of Some Osseous Points: Hunting Points or Tools?}

\section{'Isturitz Points'}

The term 'Isturitz point' (Sonneville-Bordes 1971, 1972) will be used here, rather than 'Isturitz spear' for two reasons. Firstly, the term 'spear' is a misnomer since it refers to the whole projectile weapon: from point through the shaft to the potential tail (Pétillon 1999). Second, even if we think that the term 'point' is not the most appropriate, it is nevertheless more neutral than 'spear', since it can also be applied to the active portion of a (non-projectile) tool and does not infer a sole hunting function (Goutas 2008). 
The uniquely large sample of Isturitz points at Isturitz itself provides a statistically representative corpus that allows for a detailed analysis of these objects, which are so particular in many ways (see Goutas 2008). Since its discovery, the Isturitz point has generated several hypotheses related to its function (weapon or tool) and its mode of use (Goutas 2004; Vercoutère 2004; San Juan-Foucher and Vercoutère 2005), with the aim of determining if the striated end was the proximal or the distal part of the tool. A morphological, technological, and functional study reveals that these various hypotheses are not inevitably contradictory. One part served well and truly as hunting weapons, but others were indubitably domestic tools first and foremost. It is, as such, interesting to underline that the most massive points of Isturitz, those farthest from the morphological and technical characteristics expected for a real hunting weapon, are also those reinterpreted most frequently as tools. Among these items, some present bipolar wear resulting from use as an intermediate tool, while others display non-violent stigmata and are associated with a blunt active end suggesting a use in a gesture of friction. Thus, 'Isturitz points' while being very heterogeneous in their form and size, reflect several functional realities.

In addition, I have proposed a typology for this object which retains one main criterion of distinction: the localization of the striated end, which testifies, in my opinion, to different functions according to whether it is on the proximal (group A, $n=23$ ) or distal part (group B, $n=36$ ). The rest of the assemblage consists of fragmentary artefacts (approximately $77 \%$ ), and includes a number with a 'shortened base' (3\% by 'raclage en diabolo' or sawing). Strangely, all the Gravettian sites which have produced such artefacts have a similar situation: the frequency of striated ends, the scarcity of the complete items, and the absence of complementary fragments to the striated ends. I believe this lack of nonstriated ends ensues from two factors: (1) an abandonment of these ends outside the cave for reasons linked to the function of the points; and (2) an identification problem.

The functional reallocation of some of the 'Isturitz points' as domestic tools does not mean that the inhabitants of Isturitz did not use osseous projectile points. As we have seen, nearly 150 points with morpho-technical attributes of hunting weapons are in evidence at this site. These hunting points (bevelled and simple based points) distance themselves from the Isturitz point by:

(1) A more normalized production allowing for interchangeability of points into shafts;

(2) A thinner production. Some points have a width of only about 5-6 $\mathrm{mm}$ with a thickness not exceeding $3 \mathrm{~mm}$; and

(3) A sharp active end.

Ultimately, the Isturitz point is not an entirely distinctive projectile point type, because the features which characterize it can be found on functionally very different items. It is not the Isturitz point in itself which constitutes a cultural marker of the middle phase (with Noailles burins), but instead it is a particular set of morphological attributes (and perhaps functionality) which the Gravettians applied to various categories of objects - not just projectile points. That is why, due to the diversity of the morphology, and probably the function of Isturitz points, I have suggested that the use of a more neutral term such as 'pieces with Isturitz type features' (Goutas 2008).

\section{Bipoints}

Although omnipresent in Gravettian sites, and across the Upper Paleolithic in general, bipoints constitute one of the object categories which are less well characterized. Functional hypotheses for these points are highly varied and include: straight fishhooks, a composite hunting weapon, or 'processing tools' for working plant materials (e.g., wood, bark, plants) or animal materials (leather, fur, tendons). Given the size diversity in this object category, however, it is likely that they were used for a variety of uses. If any of these bipoints turned out absolutely to be hunting weapons, it would greatly modify our conception of Gravettian weaponry, as they would significantly increase:

(1) The proportion of osseous points within assemblages; and

(2) The role of bone as the material of manufacturing this very specialized equipment.

Finally, it would highlight a phenomenon which would remain to be characterized for this period: that of 'microlithization' of osseous weapons, and its relationship with its equivalent in the field of lithic weapons.

\section{Discussion: Chronological and Sociological Perspectives on the Archaeological Data}

\section{From Aurignacian to Gravettian: A Decrease in Osseous Points?}

The Gravettian of Western Europe was, for a long time, considered as a phase of near abandonment of osseous points in favor of lithic points (Knecht 1991b; Cattelain 1995; Knecht 1997; O'Farell 2004). This idea, at least for France, has now been adjusted as the frequency of osseous projectile points are now found to be highly variable according to the assemblage and the studied facies. In some sites, points are very few (Le Flageolet I, layers VII and VI; La Gravette, lower and upper 
layers; Les Vachons, layer 3, etc.), and this is particularly the case for the early Gravettian at La Gravette/lower layer $(n=5$; Goutas 2004) and Pataud/ layer $5(n=4+2$ probable examples, Vercoutère 2004). It should be noted, however, that the osseous industry in general at these sites (with the exception of La Gravette, upper layer), are quantitatively low and often poorly preserved. In contrast, large and well preserved assemblages have a considerably larger sample of osseous points. For example, more than 150 points (excluding Isturitz points) or fragments of sharpened objects morphologically and technically compatible with this typo-functional category have been recovered from Noaillian contexts in Isturitz cave. Another hundred were found in the recent Gravettian of Laugerie-Haute, and nearly thirty in the final Gravettian of this same shelter (Goutas 2004, 2009). We must also consider if the apparent quantitative abundance of osseous points during the Aurignacian was not amplified by a particular research focus on the early Aurignacian, to the detriment of research on the end of the Aurignacian and the Gravettian.

Indeed, during the early Aurignacian, especially in the Perigord and the Pyrenees, osseous points are relatively abundant. In the 1990s, Knecht (1993:34) counted 341 split-based points in 16 French sites, however, more recent studies have greatly increased the size of the corpus of split-based points for the Aurignacian in Europe (about 700 points of this type are now known, including nearly 525 from 31 French sites [Tejero 2013, 2016]). These new data support previous hypotheses (Goutas 2009), on whether this quantitative explosion of weaponry is not a reflection of the Aurignacian standard strictly speaking, but rather corresponds more to a particular episode within this European cultural complex (the early Aurignacian), and to a regional context (southwest France) more specifically. In fact, the data are still too sparse for the very early phases (Proto-Aurignacian), as well as the recent Aurignacian (evolved Aurignacian) for setting up a chrono-cultural model, or for determining if these changes are diagnostic elements of major changes in behavior between the Aurignacian and Gravettian (Goutas 2009; Teyssandier et al. 2010; Tejero 2013).

To be able to support a real decrease of osseous weapons production and use between the Aurignacian to the Gravettian, we need detailed comparison of late Aurignacian production methods with those of the early Gravettian, taking into account differential preservation, site function, and the surrounding environment. To this end, the currently available data on the early Gravettian allows (with difficulty) a suitable comparison (Goutas 2009). For the recent phases of the Aurignacian, the only data available which does not come from a problematic or insufficiently documented stratigraphic context are those of the evolved Aurignacian from Pataud (layers 8, 7 upper and 6), however these data are still difficult to use as the osseous industry is few. Here, layer 8 delivered three osseous artefacts (not projectile points), layer
7 has 22 osseous pieces, including a fragment of an antler 'spear', and upper layer 7 is even poorer with only two pieces of osseous industry (including a lozenge based point) (Vercoutère 2004:111-132; Chiotti 2005). Finally, layer 6 delivered no examples of osseous industry at all (Gregoriani 1996). Thus, if we focus purely on the transition between the end of the Aurignacian and the beginning of the Gravettian it is difficult to assert that there was a decrease in osseous hunting weapons between these two periods.

Finally, there is no doubt that the proportion of Gravettian osseous points is currently underestimated. For France, an initial revision of this equipment (and in particular of the 'Isturitz point' type) has been provided (Goutas 2004, 2008, 2009), however, much work remains to be completed on the French corpus in order to have a precise typological and functional understanding of this technology within each site and each Gravettian phase. This situation leads us to raise another problem inherent to the Gravettian context, namely, the difficulty of creating a usable typology. This problem is the result of two reasons:

(1) The mix of technical features found on many of the points. For example, for the double-point, there is the classic one (those without a special feature), others with a flattened mesial surface, and again others with incisions engraved on their shaft. The first requires a socketlike hafting system (Fig. 7.3a), while the second requires a 'hafting by contact' system (Fig. 7.3c). The last type (those with mesial incisions) may have functioned as a type of barbed point (Peyrony 1936), but this idea is still to be confirmed (as mentioned above).

(2) The existence of a morphometric continuum between different point sub-types and perhaps between projectile points sensu stricto, as well as pointed objects which are mainly tool-making tools. The border between one type and the others still has to be defined. This case is especially true for Isturitz which provides the most important French corpus of Gravettian osseous points.

\section{Mutations in Projectile Points Features}

Let us now focus on the qualitative evolution of the points: first between the Aurignacian and Gravettian, and secondly during the Gravettian itself. In French sites, osseous projectile points are the artefact category most subject to change, however, the toolkit remains more or less stable throughout the Gravettian (Goutas 2004). In reality, this apparent stability hides subtle and complex developments. Thus, osseous tools still possess elements of chrono-cultural diagnoses which are insufficiently explored, especially when compared to the dramatic changes that accompany the evolution of hunting weapons throughout the Paleolithic. 
In France, the Gravettian introduces a major conceptual breakthrough in the size and morphology of osseous points compared with those of the Aurignacian. If we had to describe broad trends, we could say that Gravettian points are generally much narrower and longer than those of the Aurignacian (Knecht 1991a; Liolios 1999; Goutas 2004). This is not to say that there are no fine Aurignacian points, only that they are not in the majority (Tejero, personal communication). In a number of cases, this narrowness (ratio of width/thickness) is the result of repair (having led to a decrease of their initial size and volume), while others are in fact the result of deliberate design (Liolios 1999; Tejero 2013; Tartar, personal communication). Which process resulted in each of these fine points, is not yet able to be determined.

Along with a general slimming down of points during the Gravettian, the shaft section changes to a round section, along with the mesial and proximal features outlined above. Some of these changes reflect the implementation of new hafting systems.

\section{A Quantitative Development in Hunting Equipment During the Gravettian?}

Most of the osseous points date to the Middle and Recent Gravettian, with few dating to the Early and Final Gravettian. For this last phase, of the four sites associated with it (Laugerie Haute, Pataud, Le Blot, Les Peyrugues), the last two have not delivered osseous points (Chauvière and Fontana 2005; Chauvière 2012). The assemblages reported for the Early Gravettian deliver very few points also (Fig. 7.2b).

This fact is probably amplified by the state of current research where more sites and more osseous industries are known for the Middle phase of the Gravettian, while Early Gravettian assemblages are often less well preserved than those of the later Gravettian phases. We cannot, however, exclude the possibility that these quantitative differences reflect a real change in techno-economic behavior, where osseous points increase between the early phases and the middle, recent and final phases (Goutas 2009). It must be emphasized, however, that Isturitz alone accounts for about $45 \%$ of the Gravettian osseous points in France. This large cave would have been used during the Gravettian as a temporary aggregation site, where various Gravettian communities stemming from the North of Spain and from the southern part of the French Atlantic coast, would have congregated at particular times of the year to undertake economic and social practices (Lacarrière et al. 2011; Goutas and Lacarrière 2013; Normand et al. 2013). The very high frequency of osseous points (also lithic points) would therefore be connected to the execution of collective hunting at the site (essentially focused in the acquisition of bison during autumn). As previously stated, these "initial results lead us to balance the proposal made by Pike-Tay (1993) and Enloe (1993) from the study of Perigourdin sites in which Gravettians groups practiced 'opportunistic' hunting regardless of the aggregation of ungulates throughout the seasons" (Lacarrière et al. 2011:79).

Ultimately, even if it is true that in France Gravettian manufacturers mostly invested in stone for their weaponry, it nevertheless remains the case that in some sites and during certain periods, antler points also played a significant role in hunting activities (as shown by their number in the Noaillian at Isturitz cave, the recent and final Gravettian of LaugerieHaute, and to a lesser extend in the Rayssien of Arcy-sur Cure) (Goutas 2004, 2009, 2013a). Besides, it is risky to oppose lithic against antler points purely on quantitative, functional and economical grounds as there are important differences in terms of conservation, use life, maintenance, repair, raw material supply, and complexity of the manufacturing system (Knecht 1991b; Cattelain 1995; Knecht 1997). Moreover, the use of wood as a substitute to antler also needs to be considered for the final Gravettian. This use of wood could reflects its use as a substitute to antler when there was limited access to the latter (Chauvière and Fontana 2005:144; Chauvière 2012).

\section{Interpreting Changes in Gravettian Weaponry}

To understanding the mechanisms involved in the observed changes in Gravettian weaponry, it is necessary to take into account the system of manufacture of this highly specialized equipment, the global economic system of the society and the environmental constraints. Having already dealt with these issues in detail in a previous work (Goutas 2009), we will not dwell on all of our arguments, but instead focus on some important ideas which reveal the existence of close links between the introduction of a new way to produce rods ('baguettes') and the evolution of Gravettian weaponry.

\section{A Gravettian Innovation: Double Longitudinal Grooving (DLG)}

Double longitudinal grooving (also called 'groove and splinter technique' by Clark and Thompson 1953: Goutas and Tejero 2016) is clearly attested from the Gravettian period. This process, however, does not substitute Aurignacian traditions in all places. These latter methods remain used in certain phases of 
the Gravettian in France (Goutas 2003, 2009), and in the Moravian site of Pavlov I (Klima 1987; Goutas 2013b), where variants of fracturation techniques were still used on antler to production large rods - in mixing a sectioning action, an indirect percussion method ('refend'), and sometimes a short but deep groove ('rainurage/fendage').

DLG is quite simple to implement and has strong conceptual analogies with laminar knapping (Averbouh 2000). It allows the overcoming of the morphological and volumetric constraints of the osseous block, and the obtaining of perfectly predetermined blanks (lengthened, regular, narrow) which can be produced in series and favors greater standardization. In regional contexts, the place of DLG in technoeconomic systems, as well as the explanatory factors for its use, vary considerably. Omnipresent in the French Gravettian, from the earliest phases its use is scattered throughout Central Europe: rare in the Swabian Jura, better represented in Austria (in more recent contexts) (Kamegg, Willendorf II/9), and little used in Moravia during the Pavlovian period (Otte 1981; Barth et al. 2009; Goutas 2013b). In Eastern Europe, its use remains anecdotal. To understand why this new method of debitage has known such success in Western Europe, but more of a scattered appearance elsewhere, requires the identification of the underlying motivations for this technique change (Goutas 2009).

\section{New Hunting Needs, New Manufacture Methods for Osseous Points?}

DLG is not more time efficient for equipment production, nor does it make them more effective (Goutas 2009). On the other hand, and according to Knecht (1991b), Gravettian points may possess better capacity for penetration than Aurignacian points owing to their tapered shape. The use of DLG is not related to this morphological change because (as we have seen) it allows the production of long, narrow and perfectly straight blanks. On the other hand, it seems more delicate to establish a direct link between the new shape and a better capacity for penetration. Indeed, Pétillon (2006:198) comments on the experimental work of Knecht, that "Aurignacian and Gravettian points were apparently tested [in Knecht's experiments] with 'equal conditions of shootings' - same target, same shafts, same propulsion systembut can we assert that it was the same in the Paleolithic?" (author's translation).

In contrast, it appears that if DLG had been used for producing various items, hunting weapons were made exclusively using this debitage process. The invention of the DLG method is also concomitant of a change in the shape and fitting of osseous points (as discussed above). Environmental changes and changes in hunting strategies and techniques
(O'Farell 1996, 2004) could have motivated Gravettians to seek new technical solutions which allowed them to produce blanks for projectile points that were both longer, finer, lighter and more standardized (Goutas 2009). They also did not allow breakage by indirect percussion, nor the so called 're-splitting procedure' ('refend') used by their Aurignacian predecessors (Liolios 1999). However, recent experiments have helped us to improve our knowledge on this Aurignacian technique. It appears to allow control and predetermination in the blanks production (Tejero et al. 2012), however, the "rate of predetermination" is not comparable at all to that involved with the DLG which allows the reproduction of blanks, in series, exactly the same type of blank almost to the millimeter, without any limitation to length or width. That is why the term 'total predetermination' seems to me applicable only to DLG (Goutas 2004, 2009).

This change to greater standardization during the Gravettian could have been motivated by factors other than a change in manufacture method, though what modes of propulsion and tactics of game acquisition, which themselves, refer to issues of human group mobility (Cattelain 1994, 1995; Soriano 1995; Cattelain 1997; Pétillon 2006; Valentin 2006) and their demographic structure (Pelegrin 2000), still escape us. However, we note that if greater standardization of Gravettian points as against Aurignacian points cannot only be explained in terms of a change in debitage method (though shaping also plays a major role), DLG nevertheless greatly facilitates the change (Goutas 2009). In this context, the easier resharpening of Gravettian points, which can be "resharpened without modifying their general shape, while the repair of split based points - and to a lesser extent the lozenge point-requires repair on a larger scale" (after Knecht 1991b:135 in Pétillon 2006:198), as well as the possibility of better interchangeability of them in their hafts may have been a major advantage in the maintenance of this equipment (Knecht 1991a, b, 1997). This aspect was a considerable advantage if one considers it in terms of the mobility of human groups, hunting tactics implemented, and the rate of weapon loss which ensue from it (Cattelain 1995; Pelegrin 2000; O'Farell 2004). Valentin underlines that "the possibilities of maintenance to be finely estimated have to stand out both in [opportunities] which depend of the durability and the rate of loss of points, and in [facilities] which depend of the time and the working difficulty" (Valentin 2006:145, author's translation). Finally, as with lithic weapons, the greater lightness and standardization of some osseous Gravettian points could reflect the use of a new mode of propulsion (the bow?) (Cattelain and Perpère 1993; Cattelain 1997).

If the direct link between the mutations that we have just covered (appearance of the DLG, morphological change, and diversification of osseous points) remains difficult to demonstrate, it is nevertheless very likely that these convergences 
are indicative of some larger processes. Similar observations were made for stone industry and have led some researchers (Pelegrin 2000; Valentin 2006) to consider the possibility of a subtle link between "the modification of the knapping techniques, and that other capital change, transformation of hunting weapon" (Valentin 2006:142, authors translation). Although this assumption is based on different contexts to those examined herein (Magdalenian and Azilian), and mainly on stone industry, it seems interesting to examine our osseous problems in this same way. Thus, and according to Pelegrin (2000), these changes (decrease in osseous weapons in favor of new lithic weapons and changes in the terms of debitage: knapping techniques, type of used hammer, etc.) could be an expression of significant changes in hunting techniques and strategies. As such, it is interesting to highlight that it is from the middle phase of the Gravettian that artefacts associated with the use of DLG (wastes, "baguette" blanks, finished objects) become more numerous and in parallel the number of osseous points becomes consistent.

\section{A Co-Variation in the Changes Affecting Osseous and Lithic Points}

Alongside the changes that characterize Gravettian osseous artifacts, we notice in the stone industry a development and a diversification of composite weapons, including "abrupt back points", which serve as the basis for the definition of the Gravettian (O'Farell 1996; Klaric 2003; Pesesse 2003; Foucher 2004; Guillermin 2004; Simonet 2010, etc.). There is also significant investment in knapping to produce standardized blades or bladelets. The Aurignacian concept of "torsitude" (twisted blanks) (Tixier 2005) reflecting the search for a convex sharp edge (D. Pesesse, personal communication) is replaced by the "Gravettian concept" of a straight sharp edge.

According to Simonet (2005), from a dimensional point of view an important inter- and intrasite variability of Gravette points exists. This variability may reflect, depending on the context, a certain flexibility in manufacturing standards or different uses, however, most of these lithic points appeared to have served as projectile points (Cattelain and Perpère 1993; Soriano 1995; O'Farell 1996; O'Farell 2004; Simonet 2005).

\section{An Evolution of Techniques and Hunting Strategies Between the Aurignacian and the Gravettian?}

O'Farell underlined the existence of 'coincidences' or 'disturbing correlations' between the changes affecting stone weapons and environmental and faunal changes (O'Farell
1996, 2004). We shall evoke here only synthetically the conclusions of the author, which are based on an important argument which interests us for the rest of our discussion. O'Farell considers that the innovations observed in the Gravettian armament reflect an evolution of subsistence strategy (O'Farell 2004). Gravettian points (simple based points or bevelled base points) are a better adaptation to long-distance shooting, as well as greater multi-functionality, and a better capacity for maintenance than Aurignacian points. Relying particularly on ethnographic data, O'Farell questioned the possibility that the observed differences in hunting technology between the Aurignacian and Gravettian periods may reflect "the trend of the first to practice the shares of seasonal mass hunting of some species, while the second would spend more time in the acquisition of scattered animals" without it being necessary to invoke a 'specialization' of hunting (O’Farell 2004:135).

In summary, if as we suppose, there exists in France a subtle link between the emergence of the DLG method and the changes which occur in antler hunting equipment, too many unknowns (paleo-environmental, archaeozoological, technological) still limit us in our interpretations.

\section{Conclusion.... and Beginnings for Other European Contexts}

After all this background, it appears that French Gravettian sites have exhibited very specific mutations in the field of osseous hunting weapons. Nowhere else in Europe does such diversification of osseous weapons occur. Even the very rich collections of central (Pavlovian) and Eastern Europe ('Kostienki-Avdeevo culture') did not deliver a corpus as rich as those discovered in Isturitz and Laugerie-Haute. If evolutionary trends are beginning to emerge within the Gravettian hunting equipment of France, studies are still insufficient to determine precisely what these changes meant for the wider Gravettian.

In Central and Eastern Europe, the situation seems radically different (Goutas 2011, 2013b, c). On the one hand, osseous projectiles tend to be marginalized in favor of lithic points. On the other, the variety of types known in Western Europe is restricted to a more homogeneous production, dominated by the long ivory simple-based points. Presently across Europe, any of these points are sometimes decorated (Brassempouy, Predmost Ia, Avdeevo etc.). Moravian and Russian items are particularly large (dozens of centimeters in total length), whereas those of France are of a more modest size. If these dimensional differences are likely linked with differences in hunting strategies, they may also reflect a diversity of cultural conventions, or know-how in ivory working. Moravian and Russian human groups, societies 
which perfectly mastered ivory working, were able to develop technical solutions more adapted to this material resulting in the perceived differences.

The long ivory simple-based points may coexist alongside types which are sometimes exclusive of a region (e.g., Swabian Jura), or, of a site (e.g., Avdeevo). A feature of the Swabian Gravettian is both the extreme scarcity of ivory points and the use of a very particular type of point, realized on mammoth or rhino ribs (see Wolf et al. 2016). The latter seems very localized in time (early Gravettian) and space (southern Germany), and should be of high cultural value (Knecht 1991a; Barth et al. 2009). These points, oval in section, would be exclusively made from the spongy tissue and would present on some a side or facial bevel (Knecht 1993). In Russia, within the 'Kostienki-Avdeevo culture', particularly rare ivory points have been discovered in Avdeevo. These points are exceptionally lengthy (up to more than $500 \mathrm{~mm}$ ) and curved, and are characterized by a sharpened, engraved base with two side spurs (Gvozdover 1995; Goutas 2011).

Ultimately, osseous points are often few within Gravettian assemblages with the notable exception of a handful of sites (i.e., Swabian Jura and Pavlov I in Moravia). All these quantitative and qualitative changes (significant decrease in osseous points in the central and eastern European Gravettian) and qualitative (introduction of new forms and new hafting systems) undoubtedly reflect new requirements in terms of hunting strategies. If the early invention of the bow can be considered as an explanation for these changes in the Western context, mutations of the hunting weapons in Central (Moravia) and Eastern (Russian plain) Europe seems intimately linked to the emergence of more intensive occupations of large camps and important changes in lifestyle (e.g., sites occupation over the long term) and in the exploitation of the available environmental resources.

Acknowledgements I warmly thank Michelle Langley for giving me the opportunity to collaborate to this collective book. I am also very grateful to my reviewers for their useful comments and to M. Langley for her essential reading of this paper.

\section{References}

Averbouh, A. (2000). Technologie de la matière osseuse travaillée et implications palethnologiques. L'exemple des chaines d'exploitation du bois de cervidé chez les Magdaléniens des Pyrénées. Ph.D. dissertation, Université Paris I Panthéon-Sorbonne.

Cleyet-Merle, J.-J., \& Averbouh, A. (1995). Fiche Hameçons. In H. Camps-Fabrer (Ed.), Éléments barbelés et apparentés (pp. 83-89). Treignes, Belgium: CEDARC.

Alaux, J.-F. (1967-1968). Notes préliminaires sur l'abri périgordien des Battuts, commune de Penne (Tarn). Fédération Tarnaise de Spéléologie-Archéologie, 5, 37.

Baffier, D., \& Julien, M. (1990). L'outillage en os des niveaux châtelperroniens d'Arcy-sur-Cure (Yonne). Mémoires du Musée de
Préhistoire d'île de France, actes du Colloque International de Nemours, 1988. In C. Farizy \& J. Combier (Eds.), Paléolithique Moyen Récent et Paléolithique Supérieur Ancien en Europe 3 (pp. 329-341). Nemours: Ed. APRAIF.

Barth, M., Conard, N., \& Münzel, S. (2009). Palaeolithic subsistence and organic technology in the Swabian Jura. In L. Fontana, F.-X. Chauvière, \& A. Bridault (Eds.), In search of total animal exploitation. Case studies from the Upper Palaeolithic and Mesolithic. Proceedings of the XVth UISPP Congress, Session C61, 42, Lisbon, 4-9 September 2006. British Archaeological Reports. International Series 2040 (pp. 5-20). Oxford: John and Erica Hedges.

Blockeley, S. P. E., Lane, C. S., Hardiman, M., Rasmussen, S. O., Seierstad, I. K., Steffensen, J., et al. (2012). Synchronisation of palaeoenvironemental records over the last 60,000 years, and an extended INTIMATE event stratigraphy to $48,000 \mathrm{~b} 2 \mathrm{k}$. Quaternary Science Reviews, 36, 2-10.

Bordes, F. (1958). Nouvelles fouilles à Laugerie-Haute Est : premiers résultats. L'Anthropologie, 62(3, 4), 205-244.

Bricker, H. M. (1995). Le Paléolithique supérieur de l'abri Pataud (Dordogne): Les fouilles de H.-L. Movius jr. Suivi d'un inventaire analytique des sites Aurignaciens et Périgordiens de Dordogne. Paris: Maison des Sciences des Hommes, Document d'Archéologie Française 50

Bricker, H. M., \& David, N. C. (1984). Excavation of the Abri Pataud, Les Eyzies (Dordogne): The Perigordian VI (Level 3) assemblage. Cambridge, MA: Harvard University-Peabody Museum, Bulletin of American School of Prehistoric Research 34.

Cattelain, P., \& Perpère, M. (1993). Tir expérimental de sagaies et de flèches emmanchées de pointes de la Gravette. Archéo-Situla, $17-20,5-28$.

Cattelain, P. (1994). La chasse au Paléolithique supérieur : Arc ou propulseur, ou les deux ? Archéo-Situla, 21-24, 5-26.

Cattelain, P. (1995). Armatures de projectile en pierre ou en matière dure animale : Un choix lié à l'environnement? In O. Marcel (Ed.), Nature et culture. Actes du colloque de Liège, 13-17 décembre 1993 (pp. 181-185). Liège, Belgium: Service de Préhistoire, Université de Liège (ERAUL 68).

Cattelain, P. (1997). Hunting during the Upper Paleolithic: Bow, spearthrower or both? In H. Knecht (Ed.), Projectile technology (pp. 213240). New York: Plenum Press.

Chauvière, F.-X., \& Fontana, L. (2005). Modalités d'exploitation des rennes dans le Protomagdalénien du Blot (Haute-Loire, France). In V. Dujardin (Ed.), Industrie osseuse et parures du Solutréen au Magdalénien en Europe. Table ronde sur le Paléolithique supérieur récent, Angoulême (Charente, 28-30 mars 2003) (pp. 137-147). Mémoire de la Société Préhistorique Française 39.

Chauvière, F.-X. (2012). Objets d'ici et d'ailleurs : Les industries sur matières dures d'origine animale du Paléolithique supérieur du Blot (Cerzat, Haute-Loire). Préhistoire du Sud-Ouest, 20, 55-77.

Chiotti, L. (2005). Les industries lithiques aurignaciennes de l'abri Pataud, Dordogne, France: Les fouilles de Hallam L. Movius Jr. British Archaeological Reports International Series 1240. Oxford: Archaeopress.

Cleyet-Merle, J.-J. (1990). La Préhistoire de la pêche. Paris: Errance, Collection des Héspérides.

Clark, J. G. D., \& Thompson, M. W. (1953). The groove and splinter technique of working antler in Upper Palaeolithic and Mesolithic Europe. Proceedings of the Prehistoric Society, XIX(2), 148-160.

Clottes, J. (1976). Les civilisations du Paléolithique supérieur dans les Pyrénées Françaises. La Préhistoire Française, 1-2, 1214-1231.

Christensen, M. (1999). Technologie de l'ivoire au Paléolithique Supérieur: Caractérisation physico-chimique du matériau et analysefonctionnelle des outils de transformation. British Archaeological Reports International Series 751. Oxford: Hadrian Books.

David, N. C. (1985). Excavation of the Abri Pataud, Les Eyzies (Dordogne): The Noaillian (Level 4) assemblage and the Noaillian 
Culture in Western Europe. Cambridge, MA: Harvard University, Peabody Museum, ASPRB 37.

Enloe, J. G. (1993). Subsistence organization in the early Upper Paleolithic: Reindeer Hunters of the Abri du Flageolet, couche V. In H. Knecht, A. Pike-Tay, \& R. White (Eds.), Before Lascaux: The complex record of the Early Upper Paleolithic (pp. 101-115). Boca Raton, FL: CRC Press.

Flori, L. (2013). Exploitation des matières dures d'origine animale au Gravettien récent. Exemple de la couche 3 de l'abri Pataud (Dordogne). Paris: Master 2 du Muséum National d'Histoire Naturelle.

Fontaine, A. (2000). Etude d'une ancienne collection du Gravettien, Site des Vachons (Voulgezac, Charente). Bulletin de la Société Préhistorique Française, 97(2), 191-198.

Fontaine, A. (2002). Le site des Vachons (commune de VoulgézacCharente). Etude typologique de la couche 4. Paris: Mémoire de Master, Muséum d'Histoire Naturelle.

Foucher, P. (2004). Les industries lithiques du complexe GravettienSolutréen dans les Pyrénées. Techno-typologie et circulation des matières siliceuses de part et d'autre de l'axe Pyrénées-Cantabres. Thèse de doctorat, l'Université de Toulouse-Le Mirail.

Goutas, N. (1999). Les foënes et les hameçons droits au Paléolithique supérieur en France. Paris: Mémoire de Maîtrise, Université de Paris 1.

Goutas, N. (2003). Identification de deux procédés de débitage inédits du bois de Cervidés dans les niveaux Gravettiens de Laugerie-Haute Est et Ouest. Paléo, 15, 255-262.

Goutas, N. (2004). Caractérisation et évolution du Gravettien en France par l'approche techno-économique des industries en matières dures animales (étude de six gisements du Sud-ouest). Doctorat de Préhistoire, l'Université de Paris 1 - Panthéon Sorbonne.

Goutas, N. (2008). Les pointes d'Isturitz sont-elles toutes des armes de chasse? Gallia Préhistoire, 50, 45-101.

Goutas, N. (2009). Réflexions sur une innovation technique Gravettienne importante: Le double rainurage. Bulletin de la Société Préhistorique Française, 106(3), 437-456.

Goutas, N. (2011). Новые данные о восточном граветте : взгляд на костяную индустрию. In G. Khlopatchev (Ed.), Предметы вооружения и искусств $а$ из кости в древних культурах Северной Евразии (технологический и функииональный аспекты) (pp. 27-47). Замятнинский сборник 2.

Goutas, N. (2013a). Nouvelles données sur l'industrie osseuse du Gravettien des grottes d'Arcy-sur-Cure (Yonne, France): Vers l'identification de nouveaux marqueurs techniques et culturels du Gravettien moyen à burins du Raysse. In P. Bodu, L. Chechmana, L. Klaric, L. Mevel, S. Soriano, \& N. Teyssandier (Eds.), Actes de la table ronde internationale: Le Paléolithique supérieur ancien de l'Europe du Nord-Ouest. Séance de la Société Préhistorique Française (15-18 avril 2009, musée de Sens, Yonne) (pp. 89-115). Paris: Hors-Série Bulletin de la Société Préhistorique Française.

Goutas, N. (2013b). De Brassempouy à Kostienki : l'Exploitation technique des ressources animales dans l'Europe Gravettienne. In M. Otte (Ed.), Les Gravettiens (pp.105-160). Paris: Errance, Actes Sud.

Goutas, N. (2013c). New data on the osseous industry from Eastern Gravettian (Russia): Technological analyses and sociological perspectives, In F. Lang (Ed.), The sound of bones. 8th Meeting of the Worked Bone Research Group, Salzburg, August 29 (September 3th 2011) (pp. 133-154). Salzburg, Austria: Archaeoplus.

Goutas, N., \& Simonet, A. (2009). Le secteur GG2 de la grotte du Pape à Brassempouy (Landes): Un dépôt intentionnel d'armes Gravettiennes? Bulletin de la Société Préhistorique Française, 106(2), 257-291.

Goutas, N., \& Lacarrière J. (2013). L'exploitation des cervidés dans le Gravettien d'Isturitz. Une approche archéozoologique et technologique des ressources animales : De leur acquisition à leur utilisation. In C. de la Heras, J. A. Lasheras, A. Arrizabalaga, \& M. de al
Rasilla (Eds.), Pensando el Gravetiense: Nuevos datos para la región cantábrica en su contexto peninsular y pirenaico. International colloquium, Musée d'Altamira, Cantabrie, Espagne (20-22 october 2011) (pp. 565-592). Santillana del Mar, Spain: Associacíon de amigos de museo de Altamira.

Goutas, N., \& Tejero, J.-M. (2016). Osseous technology as a reflection of chronological, economic and sociological aspects of Paleolithic hunter-gatherers: Examples from key Aurignacian and Gravettian sites in South West Europe. Quaternary International, 403, 79-89.

Gregoriani, S. (1996). L'industrie osseuse et la parure des niveaux de l'abri Pataud (Les Eyzies-de-Tayac, Dordogne). Etude micromorphologique des surfaces. Paris: Mémoire de Master 2, Muséum National d'Histoire Naturelle.

Guillermin, P. (2004). Réflexions sur l'interprétation des industries Gravettiennes à partir de l'étude typo-technologique d'une occupation spécialisée: La couche E du gisement des Fieux (Miers, Lot). Mémoire de Master 2, Université de Toulouse-Le Mirail.

Gvozdover, M. (1995). Art of the mammoth hunters. The finds from Avdeevo. Oxford, England: Oxbow Monograph 49.

Kildéa, F., \& Lang, L. (2011). Le Gravettien de la vallée du Cher: Le site de la Croix de Bagneux à Mareuil-sur-Cher. In N. Goutas, L. Klaric, D. Pesesse, \& P. Guillermin (Eds.), À la recherche des identités gravettiennes: actualités, questionnements et perspectives. Actes de la table ronde internationale du 6-8 octobre 2008, Aix-enProvence (pp. 273-289). Paris: Mémoire LII de la Société Préhistorique Française.

Klaric, L. (2003). L'unité technique des industries à burins du Raysse dans leur contexte diachronique. Réflexions sur la diversité culturelle au Gravettien à partir des données de la Picardie, d'Arcy-surCure, de Brassempouy et du Cirque de la Patrie. Thèse de doctorat de Préhistoire, Université de Paris 1.

Klaric, L. (2010). Le Gravettien. In J. Clottes (Ed.), La France préhistorique (pp. 142-169). Paris: Éditions Gallimard.

Klima, B. (1987). Paleolitická Parohová industrie z Pavlova. Památky archeologiké, LXXVIII, 289-370.

Knecht, H. (1991a). Technological innovation and design during the Early Upper Paleolithic: A study of organic projectile technologies. $\mathrm{PhD}$ dissertation, New York University.

Knecht, H. (1991a). The role of innovation in changing Early Upper Paleolithic organic projectile technologies. Technique et Culture, $17-18,115-144$.

Knecht, H. (1993). Early Upper Paleolithic approaches to bone and antler projectile technology. In G. Larsen Peterkin, H. M. Bricker, \& P. Mellars (Eds.), Hunting and animal exploitation in the Later Paleolithic and Mesolithic of Eurasia (pp. 33-47). Washington, DC: Archeological Papers of the American Anthropological Association 4.

Knecht, H. (1997). Projectile technology. New York: Plenum Press.

Knecht, H. (2000). Design strategy of early Upper Paleolithic bone and antler projectile technologies. In C. Bellier, P. Cattelain, \& M. Otte (Eds.), La chasse dans la Préhistoire. Hunting in Prehistory. Actes $d u$ Colloque International de Treignes 1990, Anthropologie et Prehistoire 111, ERAUL 51 (pp. 26-38). Liège: CEDARC.

Kozlowski, S. K., \& Kozlowski, J. K. (1977). Pointes, sagaies et harpons du Paléolithique et du Mésolithique en Europe Centre-Est. In H. Camps-Fabrer (Ed.), Méthodologie appliquée à l'industrie de l'os préhistorique, actes du 2ème colloque international sur l'industrie de l'os dans la préhistoire. Abbaye de Sénanque, 9-12 juin 1976 (pp. 205-227). Paris: Colloques Internationaux du CNRS 568.

Lacarrière J., Goutas, N., Normand, C., \& Simonet, A. (2011). Vers une redéfinition des occupations Gravettiennes de la grotte d'Isturitz (Pyrénées-Atlantiques, France): Révision critique des collections "anciennes" par l'approche intégrée des données lithiques, fauniques et de l'industrie osseuse. In N. Goutas, L. Klaric, D. Pesesse, \& P. Guillermin (Eds.), À la recherche des identités Gravettiennes: Actualités, questionnements et perspectives. Actes de la table ronde internationale du 6-8 octobre 2008, 
Aix-en-Provence (pp. 67-83). Paris: Mémoire LII de la Société Préhistorique Française.

Langley, M. C., Pétillon, J.-M., \& Christensen, M. (2016). Diversity and evolution of osseous hunting equipment during the Magdalenian (21,000-14,000 cal. BP). In M. C. Langley (Ed.), Osseous projectile weaponry: Towards an understanding of Pleistocene cultural variability (pp. 143-159). Dordrecht: Springer.

Liolios, D. (1999). Variabilité et caractéristique du travail des matières osseuses au début de l'Aurignacien, Approche technologique et économique. Thèse de doctorat, Université de Paris X

Normand C., Goutas, N., Lacarrière, J., \& Simonet, A. (2013). El Gravetiense de la cueva de Isturitz : Nuevas investigaciones, nuevos datos. In C. de las Heras, J. A. Lasheras, A. Arrizabalaga, M. de la Rasilla (Eds), Pensando el Gravetiense: nuevos datos para la región cantábrica en su contexto peninsular y pirenaico. International colloquium, Musée d'Altamira, Cantabrie, Espagne (20-22 October 2011) (pp. 161-183). Santillana del Mar, Spain: Associacíon de amigos de museo de Altamira.

O'Farell, M. (1996). Approche technologique et fonctionnelle des pointes de la Gravette, une analyse archéologique et expérimentale appliquée à la collection de Corbiac (Dordogne). Mémoire de Master 2, Université de Bordeaux I.

O'Farell, M. (2004). Les pointes de la Gravette de Corbiac (Dordogne) et considérations sur la chasse au Paléolithique supérieur ancien. In $\mathrm{P}$. Bodu, \& C. Clude (Eds.), XXVe Congrès préhistorique de France, Nanterre 24-26 novembre 2000, Approches fonctionnelles en Préhistoire (pp. 121-128). Paris: Société Préhistorique Française.

Otte, M. (1981). Le Gravettien en Europe Centrale. Dissertationes Archaeologicae Gandenses, Bruges, De Tempel.

Pesesse, D. (2008). Les premières sociétés Gravettiennes. Analyse comparée des systèmes lithiques de la fin de l'Aurignacien aux débuts du Gravettien. Mémoire de doctorat, Université Aix-Marseille.

Pesesse, D. (2013). Le Gravettien existe-t-il ? Le prisme du système technique lithique. In M. Otte (Ed.), Les Gravettiens (pp. 65-102). Paris: Errance, Actes Sud.

Pelegrin, J. (2000). Les techniques de débitage laminaire au Tardiglaciaire: Critères de diagnose et quelques réflexions. In B. Valentin, P. Bodu, \& M. Christensen (Eds.), l'Europe centrale et septentrionale au Tardiglaciaire. Table ronde de Nemours, 13-16 mai 1997 (pp. 73-86). Mémoires du musée de Préhistoire d'Île-deFrance, 7.

Pétillon, J.-M. (1999). Les pointes à base fourchue Magdaléniennes. Problèmes typologiques, techniques et fonctionnels. Mémoire de Master 2, Université de Paris 1.

Pétillon, J.-M. (2006). Des Magdaléniens en armes. Technologie des armatures de projectile en bois de cervidé du Magdalénien supérieur de la grotte d'Isturitz, (Pyrénées-Atlantiques). Paris: CEDARC.

Peyrony, D. (1932). Les Gisements préhistoriques de Bourdeilles (Dordogne). Archives de l'Institut de Paléontologie Humaine 10. Paris: Masson.

Peyrony, D. (1936). Le Périgordien et l'Aurignacien (Nouvelles observations). Bulletin de la Société Préhistorique Française, 33(11), 616-619.

Peyrony, D. (1939). Fouilles à la Roque-Saint-Christophe, commune de Peyzac-le-Moustier (Dordogne). Bulletin de la Société Historique et Archéologique du Périgord, 3-4, 248-269, 360-387.

Peyrony, D., \& Peyrony, E. (1938). Laugerie-Haute près des Eyzies (Dordogne). Archives de l'institut de paléontologie humaine 19. Paris: Masson.

Peyrony, E. (1934). Le gisement de La Forêt, commune de Tursac (Dordogne). XIe session du Congrès Préhistorique de France, Périgueux. Bulletin de la Société Préhistorique Française, 31, 424-430.

Pesesse, D. (2003). Approche du comportement technique au Gravettien: L'industrie lithique de l'unité OP10 de la Vigne Brun. Mémoire de D.E.A., Université de Provence, Aix-en-provence.
Pike-Tay, A. (1993). Hunting in the Upper Perigordian: A matter of strategy or expedience? In H. Knecht, A. Pike-Tay, \& R. White (Eds.), Before Lascaux: The complex record of the Early Upper Paleolithic (pp. 85-99). Boca Raton, FL: CRC Press.

Pokines, J., \& Krupa, M. (1997). Self-barbed antler spearpoints and evidence of fishing in the Late Upper Paleolithic of Cantabrian Spain. In H. Knecht (Ed.), Projectile technology (pp. 241-262). New York: Plenum Press.

San Juan-Foucher, C., \& Vercoutère, C. (2005). Les "sagaies d'Isturitz" des niveaux gravettiens de Gargas (Hautes-Pyrénées) et de Pataud (Dordogne). Un exemple d'approche pluridisciplinaire et complémentaire de l'industrie osseuse. Préhistoire Anthropologie Méditerranéennes, 12, 75-94.

San Juan-Foucher, C. (2005). Aiguilles, sagaies et pendeloques: l'industrie solutréenne sur matière dure animale de l'abri des Harpons (Lespugue, Haute-Garonne). In V. Dujardin (Ed.), Industrie osseuse et parures du Solutréen au Magdalénien en Europe, Actes du Colloque international d'Angoulême, 28-30 mars 2003 (pp. 161-176). Paris: Mémoire de la Société Préhistorique Française, 39.

Saint-Périer R., \& Saint-Périer, S. (1952). La grotte d'Isturitz III: Les Solutréens, les Aurignaciens et les Moustériens. Archives de 1'Institut de Paléontologie Humaine 25. Paris: Masson.

Sanchez-Goñi, M. F., \& Harrison, S. P. (2010). Millennial-scale variability and vegetation changes during the last glacial: Concepts and terminology. Quaternary Science Reviews, 29(21-22), 2823-2827.

Simonet, A. (2005). Les armatures lithiques. Méthodes d'étude et enjeux : l'exemple des armatures gravettiennes d'Isturitz, Mémoire de DEA de 1'Université de Toulouse II - Le Mirail.

Simonet, A. (2009). Les Gravettiens des Pyrénées. Des armes aux sociétés. Munibe, 60, 81-98.

Simonet, A. (2010). Typologie des armatures lithiques Gravettiennes de la grotte d'Isturitz (Pyrénées-Atlantiques, France). British Archaeological Reports. British Archaeological Reports International Series 2156. Oxford: Archaeopress.

Simonet, A. (2011). La pointe des Vachons: Nouvelles approches d'un fossile directeur controversé du Gravettien à partir des exemplaires du niveau IV de la grotte d'Isturitz (Pyrénées-Atlantiques, France) et des niveaux 4 des abris 1 et 2 des Vachons (Charente, France). Paleo, 22, 271-298.

Sonneville-Bordes, D. (1960). Le Paléolithique Supérieur en Périgord. Bordeaux, France: Imprimere Delmas, CNRS.

Sonneville-Bordes, D. (1971). Un fossile directeur osseux du Périgordien à burins de Noailles. Bulletin de la Société Préhistorique Française, 68(2), 44-45.

Sonneville-Bordes, D. (1972). A propos des pointes osseuses à extrémité striée du Périgordien à burins de Noailles. Bulletin de la Société Préhistorique Française, 69(2), 37-38.

Soriano, S. (1995). Analyse conceptuelle et fonctionnelle des pointes à dos microlithiques au Périgordien supérieur. Application à la série de Rabier (Lanquais, Dordogne). Mémoire de Maîtrise, Université de Paris X.

Stordeur D. (1987). Manches et emmanchements préhistoriques: quelques propositions préliminaires. In D. Stordeur (Ed.), La Main et l'Outil. Manches et emmanchements préhistoriques. Table Ronde C.N.R.S. tenue à Lyon du 26 au 29 Novembre 1984 (pp. 11-34). Lyon, France: Travaux de la Maison de l'Orient.

Tartar, E. (2009). De l'os à l'outil. Caractérisation technique, économique et sociale de l'utilisation de l'os à l'Aurignacien ancien Étude de trois sites : 1'Abri Castanet (secteurs nord et sud), Brassempouy (Grotte des Hyènes et Abri Dubalen) et Gatzarria, Thèse de doctorat, Université Paris I, Paris.

Tartar, E., \& White, R. (2013). The manufacture of Aurignacian splitbased points: An experimental challenge. Journal of Archaeological Science, 40(6), 2723-2745. 
Tejero, J. M. (2013). La explotación de las materias óseas en el Auriñaciense. Caracterización tecnoeconómica de las producciones del Paleolítico superior inicial en la Península Ibérica. British Archaeological Reports International Series 2469. Oxford: Archaeopress.

Tejero, J.-M. (2016). Spanish Aurignacian projectile points: An example of the first European palaeolithic hunting weapons in osseous materials. In M. C. Langley (Ed.), Osseous projectile weaponry: Towards an understanding of Pleistocene cultural variability (pp. 55-69). Dordrecht: Springer.

Tejero, J. M., Christensen, M., \& Bodu, P. (2012). Red Deer Antler technology and early Modern Humans in Southeast Europe: An experimental study. Journal of Archaeological Science, 39(2), 332-346.

Teyssandier, N., Bon, F., \& Bordes, J.-G. (2010). Within projectile range: Some thoughts on the appearance of the Aurignacian in Europe. Journal of Anthropological Research, 66, 209-229.

Tixier, J. (2005). Torsitude à Ksar 'Aquil (Liban). In F. Lebrun Ricalens, J.-G. Bordes, \& F. Bon (Eds.), Productions lamellaires attribuées à
l'Aurignacien, chaînes opératoires et perspectives technoculturelles. Actes du XIVe congrès de l'Union internationale des sciences pré et protohistoriques, Université de Liège, 2-8 Septembre 2001 (pp. 19-21). Luxembourg: Archéologiques 1, MNHA.

Valentin, B. (2006). De l'Oise à la Vienne, en passant par le Jourdain. Jalons pour une Paléohistoire des derniers chasseurs. Mémoire de Thèse d'Habilitation à Diriger des Recherches, Université de Paris 1.

Vercoutère, C. (2004). Exploitation de l'animal comme ressource de matières premières non alimentaires: Industrie osseuse et parure. Exemple de l'abri Pataud (Dordogne, France). Thèse du Muséum d'Histoire Naturelle.

Wolf, S., Münzel, S., Dotzel, K., Barth, M. M., \& Conard, N. J. (2016). Projectile weaponry from the Aurignacian to the Gravettian of the Swabian Jura (Southwest Germany): Raw materials, manufacturing and typology. In M. C. Langley (Ed.), Osseous projectile weaponry: Towards an understanding of Pleistocene cultural variability (pp. 71-87). Dordrecht: Springer. 